\title{
Efficacy of $1400 \mathrm{~W}$, a novel inhibitor of inducible nitric oxide synthase, in preventing interleukin-1 $\beta$-induced suppression of pancreatic islet function in vitro and multiple low-dose streptozotocin-induced diabetes in vivo
}

Tobias Rydgren and Stellan Sandler

Department of Medical Cell Biology, Uppsala University, Uppsala, Sweden

(Correspondence should be addressed to Tobias Rydgren, Department of Medical Cell Biology, Biomedicum, PO Box 571, SE-751 23 Uppsala, Sweden; Email: Tobias.Rydgren@medcellbiol.uu.se)

\begin{abstract}
Objective: Nitric oxide (NO), generated by inducible nitric oxide synthase (iNOS), has been implicated in $\beta$-cell destruction in type 1 diabetes. In the present study, we tested a highly selective iNOS inhibitor, $1400 \mathrm{~W}$, against interleukin-1 $\beta$ (IL-1 $\beta$ ) induced suppression of rat pancreatic islets, and investigated whether $1400 \mathrm{~W}$ could prevent multiple low-dose streptozotocin (MLDS) induced diabetes in mice. Furthermore, we studied if $1400 \mathrm{~W}$ affected lipopolysaccharide (LPS) induced increase in plasma nitrite + nitrate $\left(\mathrm{NO}_{x}\right)$ in mice.

Design and methods: Precultured rat pancreatic islets were exposed for $48 \mathrm{~h}$ to $0,1,10$ or $50 \mu \mathrm{mol} / \mathrm{l}$ $1400 \mathrm{~W}$ in the presence or absence of $25 \mathrm{U} / \mathrm{ml} \mathrm{IL}-1 \beta$, whereupon islet functions were analyzed. MLDS-treated mice were given $5.9 \mathrm{mg} / \mathrm{kg}$ body weight of $1400 \mathrm{~W}$ intraperitoneally daily or $14 \mathrm{mg} / \mathrm{kg}$ body weight twice a day. Blood glucose was monitored and degree of pancreatic mononuclear infiltration was determined. Mice previously injected intraperitoneally with LPS $(500 \mu \mathrm{g})$ were given $1400 \mathrm{~W}(14 \mathrm{mg} / \mathrm{kg}$ body weight $)$ intraperitoneally and plasma $\mathrm{NO}_{x}$ was determined after 3,6 and $10 \mathrm{~h}$

Results: The inhibitor alone did not affect islet functions. $1400 \mathrm{~W}(50 \mu \mathrm{mol} / \mathrm{l})$ fully counteracted both the suppression of glucose oxidation rate, (pro)insulin biosynthesis and nitrite accumulation caused by IL-1 $\beta$. Cytokine-induced decrease in medium insulin accumulation and glucose-stimulated insulin release was partly counteracted by $1400 \mathrm{~W}$, suggesting that inhibition of insulin release was partially NO independent. LPS-induced increase in plasma $\mathrm{NO}_{x}$ was markedly inhibited for up to $10 \mathrm{~h}$ after $1400 \mathrm{~W}$ administration. Irrespective of $1400 \mathrm{~W}$ treatment, animals treated with MLDS developed hyperglycemia and pancreatic insulitis.

Conclusions: $1400 \mathrm{~W}$ counteracted IL-1 $\beta$-induced suppression of rat islets in vitro and LPS induction of $\mathrm{NO}_{x}$ in vivo, however, it failed to protect against MLDS diabetes in vivo. The latter might be due to a failure by $1400 \mathrm{~W}$ in vivo to inhibit NO formation at the level of the pancreatic islet.
\end{abstract}

European Journal of Endocrinology 147 543-551

\section{Introduction}

Type 1 diabetes mellitus is believed to be an autoimmune disease in which the T-cells and macrophages invade the islets of Langerhans in the pancreas. It is suggested that these mononuclear cells, either directly or through the release of inflammatory mediators such as cytokines, e.g. interleukin-1 $\beta$ (IL-1 $\beta$ ) and interferon- $\gamma($ IFN- $\gamma)$, and free radicals cause the specific $\beta$-cell destruction that occurs in type 1 diabetes (1).

The radical nitric oxide (NO) is produced, directly or indirectly, from L-arginine by the enzyme NO synthase (NOS) (2) in many mammalian cells. The neuronal
NOS (nNOS) and the endothelial NOS (eNOS) isoforms are $\mathrm{Ca}^{2+}$ dependent and mostly expressed constitutively with a relatively low NO output $(2,3)$. The inducible NOS (iNOS) isoform, which has been suggested to be involved in $\beta$-cell destruction $(4,5)$, is largely or completely independent of $\mathrm{Ca}^{2+}(2,3)$. This isoform is mostly not expressed under normal conditions but can be induced by, for instance, cytokines and endotoxins to produce large amounts of NO that in this case often function as a cytostatic and a cytotoxic molecule $(2,3,6)$.

It has been found that both human and rodent pancreatic $\beta$-cells express iNOS and produce NO in 
response to cytokines in vitro $(7,8)$. Furthermore, it has been shown that iNOS is expressed by both $\beta$-cells and activated macrophages in the pancreatic islets during the pre-diabetic insulitis in certain strains of mice and rats that spontaneously develop type 1 diabetes $(9,10)$. Flodström et al. also showed that iNOS knockout mice are resistant to diabetes induced by multiple low doses of streptozotocin (MLDS) (11).

These findings have raised interest in the question of whether inhibitors of iNOS could be used to prevent the development of type 1 diabetes. However, if this were the case, a high selectivity for iNOS vis-à-vis nNOS and eNOS seems important to prevent side effects that might arise from inhibiting the other isoforms (2). Recently, Suarez-Pinzon et al. reported that an iNOS inhibitor and scavenger of peroxynitrite, guanidinoethyldisulfide (GED), delayed the onset of diabetes in non-obese diabetic (NOD) mice from 12 to 22 weeks (12). However, according to the criteria put forward by Alderton et al., this inhibitor is at best a 'partially' selective iNOS inhibitor (2).

Against this background we decided to test if a new and 'highly' selective inhibitor of iNOS called $1400 \mathrm{~W}$ (N-(3-(aminomethyl)benzyl)acetamidine) $(2,13)$ could prevent the IL-1 $\beta$-induced suppression of pancreatic islet function in vitro. It has been shown that inhibition of human iNOS by $1400 \mathrm{~W}$ competes with L-arginine and the reaction is NADPH dependent (2). The mechanism for inhibition is considered to be either irreversible or very slowly reversible (2). Depending on our results with $1400 \mathrm{~W}$, we also aimed to examine if the compound could prevent MLDS-induced diabetes in vivo.

\section{Materials and methods}

\section{Isolation and culture of pancreatic islets}

Adult Sprague-Dawley rats were anesthetized and killed by cervical dislocation, pancreatic tissue removed and digested by collagenase. Pancreatic islets were then handpicked under a stereomicroscope. Islets were cultured free-floating in medium RPMI-1640 supplemented with $10 \%$ fetal calf serum $(\mathrm{FCS}, \mathrm{vol} / \mathrm{vol})$. Islet cultures were kept at $37^{\circ} \mathrm{C}$ in air $+5 \% \quad \mathrm{CO}_{2}$ for $6-7$ days with medium changes every second day.

\section{Islet treatment}

Islets were subsequently divided into groups of 50 and cultured in a volume of $2.5 \mathrm{ml}$ for $48 \mathrm{~h}$ as described above, with different additives. Three groups were cultured with $1400 \mathrm{~W}(1,10$ and $50 \mu \mathrm{mol} / \mathrm{l}$; Alexis Biochemicals, Lausen, Switzerland), one group with $\mathrm{IL}-1 \beta(25 \mathrm{U} / \mathrm{ml})$, and another three groups with both IL-1 $\beta$ and $1400 \mathrm{~W}$. Islets cultured without any additives served as a control group. The islets were then subjected to further experiments and analysis as described below. Medium without islets was also kept under the same conditions, to use as a blank for the analysis of medium nitrite content and medium insulin accumulation.

\section{Analysis of medium nitrite content}

The determination of medium nitrite content was performed using the Griess reagent $(0.5 \%$ naphthylethylenediamine dihydrochloride, 5\% sulfanilamide, and $\left.25 \% \mathrm{H}_{2} \mathrm{PO}_{4}\right)(14)$. A $10 \mu \mathrm{l}$ volume of recently prepared Griess reagent was added to $100 \mu \mathrm{l}$ samples of culture medium and incubated at $60^{\circ} \mathrm{C}$ for $2 \mathrm{~min}$. The reaction products were then measured spectrophotometrically ( $\lambda=546 \mathrm{~nm}$ ) and the amount of nitrite in the samples calculated by the use of a standard curve. All determinations (including the standard curve) were performed in triplicates.

\section{Determination of islet glucose oxidation rate}

Groups of 10 islets were incubated in glass vials containing $100 \mu \mathrm{l}$ of Krebs-Ringer buffer supplemented with $10 \mathrm{mmol} / \mathrm{l}$ HEPES (Sigma), D-[U-14C]glucose (Amersham-Pharmacia Biotech, Amersham, UK) and non-radioactive glucose to give a final concentration of $16.7 \mathrm{mmol} / \mathrm{l}$. The vials were placed in glass scintillation vials, with its shafts squeezed through rubber membranes, gassed with 95\% $\mathrm{O}_{2}$ and $5 \% \mathrm{CO}_{2}$ and sealed tightly. The vials were then incubated in a slow-shaking water bath $(30$ strokes $/ \mathrm{min})$ at $37^{\circ} \mathrm{C}$ for $90 \mathrm{~min}$ before the glucose oxidation was terminated with $100 \mu \mathrm{l}$ of $0.05 \mathrm{mmol} / \mathrm{l}$ antimycin A (Sigma) (dissolved in $99.9 \%$ ethanol), injected through the membrane into the inner vial. In the same way, $100 \mu \mathrm{l}$ of $0.4 \mathrm{~mol} / \mathrm{I} \mathrm{Na}_{2} \mathrm{HPO}_{4}(\mathrm{pH}$ 6.0) was injected to release the $\mathrm{CO}_{2}$ formed. The $\mathrm{CO}_{2}$ was then trapped by injection of $250 \mu \mathrm{l}$ Hyamine 10-X (New England Nuclear, Boston, MA, USA) into the outer vial before incubating for another $2 \mathrm{~h}$ at $37^{\circ} \mathrm{C}$. Finally $5 \mathrm{ml}$ of Ultima Gold scintillation liquid (Packard Instrument, Meriden, CT, USA) was added and the radioactivity was measured by liquid scintillation counting. Triplicate samples were used for all determinations, and vials with medium but without islets were used as blank.

\section{Determination of medium insulin accumulation, glucose-induced insulin release, insulin, and DNA contents}

For all of the insulin determinations we used a rat insulin ELISA (Mercodia, Uppsala, Sweden). To determine the glucose-induced insulin release, duplicate groups of 10 islets were first incubated in $100 \mu \mathrm{l}$ Krebs-Ringer buffer, supplemented with $10 \mathrm{mmol} / \mathrm{l}$ HEPES, $16.7 \mathrm{mmol} / \mathrm{l}$ glucose and $2 \mathrm{mg} / \mathrm{ml}$ BSA (ICN Biomedicals, Aurora, OH, USA), for $90 \mathrm{~min}$ at $37^{\circ} \mathrm{C}$. 
To determine the insulin and DNA contents from these glucose-stimulated islets, the islets were ultrasonically disrupted in $200 \mu \mathrm{l}$ redistilled water. A $50 \mu \mathrm{l}$ volume of the homogenate was then mixed with $125 \mu \mathrm{l}$ of acid ethanol $(0.18 \mathrm{~mol} / \mathrm{l} \mathrm{HCl}$ in $96 \% \mu \mathrm{l}$ ( $\mathrm{vol} / \mathrm{vol})$ ethanol) and insulin was extracted at $4{ }^{\circ} \mathrm{C}$ overnight before determination. Another two $50 \mu \mathrm{l}$ aliquots from the homogenate were used to determine the DNA contents by a fluorophotometric method (15).

\section{Determination of islet (pro)insulin biosynthesis and total protein biosynthesis}

Groups of 10 islets were incubated in duplicate for $2 \mathrm{~h}$ in $100 \mu \mathrm{l}$ of Krebs-Ringer buffer containing $2 \mathrm{mg} / \mathrm{ml}$ BSA, $16.7 \mathrm{mmol} / \mathrm{l}$ glucose and $50 \mu \mathrm{Ci} / \mathrm{ml}$ L- $\left[4.5-{ }^{3} \mathrm{H}\right]$ leucine (Amersham-Pharmacia Biotech, Uppsala, Sweden) at $37^{\circ} \mathrm{C}$ in air $+5 \% \mathrm{CO}_{2}$. After incubation the islets were washed, in Hanks' balanced salt solution containing $10 \mathrm{mmol} / \mathrm{l}$ non-radioactive leucine, and then sonicated in $200 \mu \mathrm{l}$ redistilled water.

From each sample, $4 \times 10$ aliquots were transferred to Eppendorf tubes for (pro)insulin analysis according to Halban et al. (16). To the tubes, $100 \mu$ l of glycine buffer with Triton X-100 were added before adding $10 \mu \mathrm{l}$ of guinea pig anti-bovine insulin serum (ICN Biochemicals, Cosa Mesa, CA, USA) to two of the tubes and $10 \mu \mathrm{l}$ of guinea pig serum (for non-specific antibody binding) to the other two. The tubes were mixed vigorously and incubated at room temperature for $1 \mathrm{~h}$. The samples were then mixed again and $100 \mu \mathrm{l}$ of protein A-Sepharose (Amersham-Pharmacia) solution were added before incubating for another 15 min during slow shaking. The samples were then centrifuged $(30 \mathrm{~s}$ at $500 \boldsymbol{g})$ and washed twice with $0.5 \mathrm{ml}$ of glycine buffer containing Triton X-100. The pellets were resuspended in $2 \times 250 \mu \mathrm{l}$ acetic acid solution and transferred to scintillation vials before $4 \mathrm{ml}$ Ultima Gold scintillation liquid was added and the samples counted in a liquid scintillation counter. A mean was calculated for the two guinea pig serum tubes and subtracted from the calculated mean for the two anti-insulin serum tubes to obtain a measure of the (pro)insulin biosynthesis rate.

For the analysis of total protein biosynthesis rate, we took $2 \times 10 \mu \mathrm{l}$ aliquots from the water homogenate samples of sonicated islets and transferred these to Eppendorf tubes. We added $250 \mu \mathrm{l}$ of glycine solution and $250 \mu \mathrm{l}$ of trichloroacetic acid and mixed vigorously. The samples were centrifuged (10 min at 2000 r.p.m.), the supernatant removed and the pellets dissolved in $2 \times 250 \mu \mathrm{l}$ of $0.15 \mathrm{~mol} / \mathrm{l} \mathrm{NaOH}$ and transferred to scintillation vials before $4 \mathrm{ml}$ Ultima Gold scintillation liquid was added and the samples counted in a liquid scintillation counter.

\section{In vivo protocol 1}

Inbred, 10-13-week-old male C57BL/Ks mice (Biomedical Center, Uppsala, Sweden) were used. The mice had free access to tap water and pelleted food (R36; AnaLyzen, Lidköping, Sweden). The mice were divided into four groups (five mice per group) with different kinds of treatment: citrate buffer + saline; citrate buffer $+1400 \mathrm{~W}$; streptozotocin $(\mathrm{STZ})+$ saline; and STZ $+1400 \mathrm{~W}$. Once a day, the mice first received an intraperitoneal injection of either citrate buffer $(\mathrm{pH}$ $4.5 ; 0.2 \mathrm{ml})$ or STZ $(40 \mathrm{mg} / \mathrm{kg}$ body weight; $0.2 \mathrm{ml})$ dissolved in citrate buffer, and then after $30 \mathrm{~min}$ they received another intraperitoneal injection of either saline $(9 \mathrm{~g} / \mathrm{l} ; 0.2 \mathrm{ml})$ or $1400 \mathrm{~W}(5.9 \mathrm{mg} / \mathrm{kg}$ body weight; $0.2 \mathrm{ml}$ ) dissolved in saline. This treatment was maintained for five consecutive days after which only the saline/1400 W injections were given for another 5 days. Blood glucose determinations were performed on blood samples taken from the tail tip of non-fasted mice on day 0 , before any injections, and on days 3, 7, 10 and 14. Blood glucose was measured by a blood glucose meter (Medisense, London, UK). The mice were weighed on days 0,7 and 14 and killed for morphologic examination of the pancreatic glands on day 14 .

\section{In vivo protocol 2}

Based on the results from protocol 1 and a study by Parmentier et al. (17), we tested another protocol. This time we increased the injected dose of the iNOS inhibitor to $14 \mathrm{mg} / \mathrm{kg}$ body weight and gave the saline/1400 W injections twice a day $(\sim 10 \mathrm{~h}$ between the first and second injection every day), thus increasing the daily dose of the inhibitor by almost five times. The mice in this study were 14-18 weeks old.

\section{Morphologic examination}

The mice were killed by cervical dislocation, the pancreatic glands removed and fixed in $10 \%$ formalin for $24 \mathrm{~h}$, after which they were embedded in paraffin and cut into $5 \mu \mathrm{m}$ thin sections. These sections were stained with hematoxylin and eosin and examined under a microscope. The pancreatic islet histology was ranked into four arbitrary classes where class A denotes normal islet structure; class B mononuclear cell infiltration in the islet peri-insular area; class $\mathrm{C}$ heavy mononuclear cell infiltration into a majority of islets, i.e. insulitis; and class D only a few residual islets present, often showing an altered architecture and pyknotic cell nuclei (18). The examiner was unaware of the origin of the sections. 


\section{Determination of total plasma nitrite and nitrate $\left(\mathrm{NO}_{\mathrm{x}}\right)$ in vivo}

The same strain of inbred C57BL/Ks mice were used, as in protocol 1 and 2, with free access to food and water, although, in this study we used both males and females and their ages ranged from 10 to 17 weeks. The mice were divided into three groups with different kinds of treatment: saline + saline, lipopolysaccharide (LPS from E. coli (Sigma-Aldrich, Stockholm, Sweden)) + saline and LPS $+1400 \mathrm{~W}$. First the mice received an intraperitoneal injection of either saline $(9 \mathrm{~g} / \mathrm{l} ; 0.2 \mathrm{ml})$ or LPS $(500 \mu \mathrm{g} ; 0.2 \mathrm{ml})$ dissolved in saline, and then after $3 \mathrm{~h}$ they received another intraperitoneal injection of either saline or $1400 \mathrm{~W}(14 \mathrm{mg} / \mathrm{kg}$ body weight; $0.2 \mathrm{ml}$ ) dissolved in saline. After another 3,6 or $10 \mathrm{~h}$, retro-orbital venous blood samples were collected before mice were killed by cervical dislocation. Samples were centrifuged at $4000 \boldsymbol{g}$ for $5 \mathrm{~min}$ and plasma collected. $\mathrm{NO}_{x}$ levels were determined by the use of the spectrophotometric assay kit BIOXYTECH NO-540 (Oxis Research, Portland, OR, USA) according to the manufacturer's instructions. This assay kit uses cadmium to reduce nitrate to nitrite before using the Griess reaction and measuring the absorbance at $540 \mathrm{~nm}$.

\section{Statistical analysis}

Data are presented as means \pm S.E.M. and groups of data were compared by one-way repeated ANOVA, with subsequent all pairwise comparison procedures by Bonferroni $t$-test or Student-Newman-Keuls method using SigmaStat (SPSS Inc., Chicago, IL, USA).

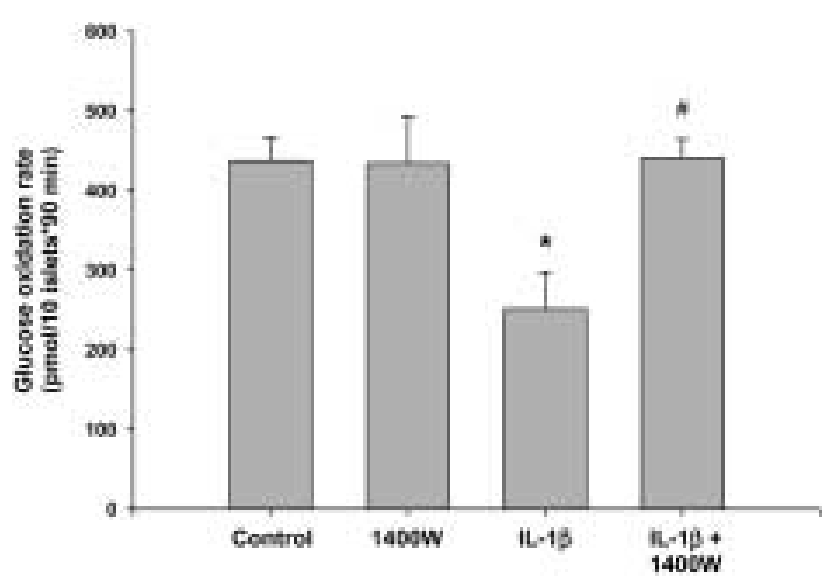

Figure 1 Glucose oxidation rates in islets cultured for $48 \mathrm{~h}$ with or without $1400 \mathrm{~W}(50 \mu \mathrm{mol} / \mathrm{l})$ and in the presence or absence of $\mathrm{IL}-1 \beta(25 \mathrm{U} / \mathrm{ml})$. Values are means \pm S.E.M. for four experiments. * denotes $P<0.01$ vs control and \# denotes $P<0.01$ vs IL-1 $\beta$ value, using one-way repeated ANOVA with subsequent all pairwise comparison procedures by Bonferroni $t$-test.

\section{Results}

Pancreatic islets, cultured with IL-1 $\beta$ for $48 \mathrm{~h}$, showed a marked inhibition of glucose oxidation rate $(58 \%$ of the control group), which was fully counteracted by $1400 \mathrm{~W}$ at the highest concentration (50 $\mu \mathrm{mol} / \mathrm{l})$ (Fig. 1). However, no such significant counteraction was seen at the lower concentrations (1 and $10 \mu \mathrm{mol} / \mathrm{l}$ ) (data not shown). Incubations with $1400 \mathrm{~W}$ alone showed no significant changes in glucose oxidation rate. In fact, the inhibitor alone did not cause any significant change, compared with the control, in any of our in vitro experiments. Neither did we, in any of the experiments, observe any significant counteraction of the IL-1 $\beta$-induced effects at the lowest concentration of $1400 \mathrm{~W}$ (1 $\mu \mathrm{mol} / \mathrm{l})$.

The medium nitrite accumulation of the islets cultured with IL-1 $\beta$ was increased about threefold compared with the control value. This increase was also fully prevented by the addition of $1400 \mathrm{~W}$ (50 $\mu \mathrm{mol} / \mathrm{l})$ with no significant difference between control and IL-1 $\beta+1400 \mathrm{~W}$ (Fig. 2). With the addition of the intermediate concentration $(10 \mu \mathrm{mol} / \mathrm{l})$, only a minor decrease (about 25\% less nitrite accumulation) was seen (not shown).

The amount of insulin accumulation in the medium during a 48 -h culture of islets with IL-1 $\beta$ was decreased to $23 \%$ of the control value (Fig. 3). This was partly prevented by $50 \mu \mathrm{mol} / \mathrm{l}$ of $1400 \mathrm{~W}$ to $63 \%$.

Similarly, the amount of insulin released by islets (previously exposed to IL-1 $\beta$ ) during incubation in $16.7 \mathrm{mmol} / \mathrm{l}$ glucose was decreased to $12 \%$ of the control value. Using the highest concentration of $1400 \mathrm{~W}$, we observed an increase of this value to about $60 \%$ of the control value (Fig. 4 ).

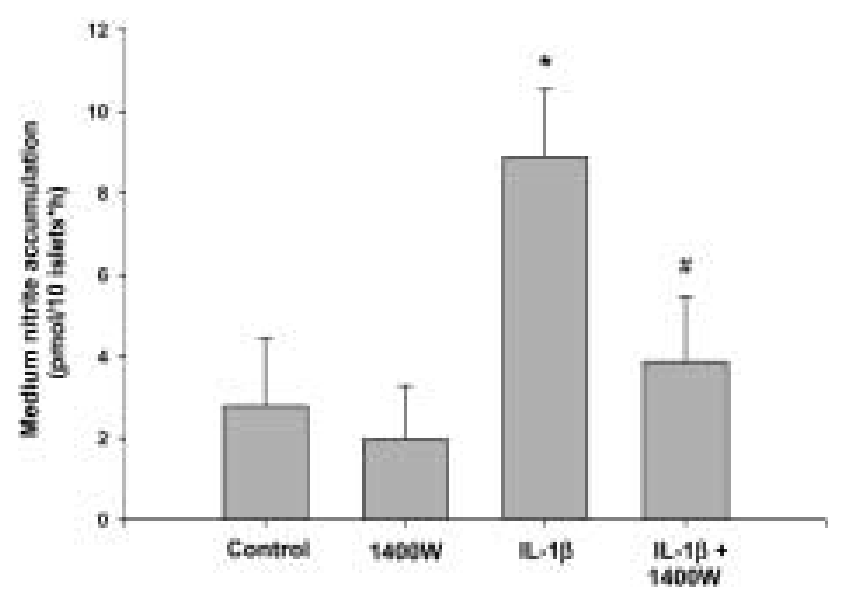

Figure 2 Medium nitrite accumulation after a 48-h culture of islets with or without $1400 \mathrm{~W}(50 \mu \mathrm{mol} / \mathrm{l})$ and in the presence or absence of IL-1 $\beta(25 \mathrm{U} / \mathrm{ml})$. Values are means \pm S.E.M. for 10 experiments. * denotes $P<0.001$ vs control value and \# denotes $P<0.001$ vs IL-1 $\beta$ value, using one-way repeated ANOVA with subsequent all pairwise comparison procedures by Bonferroni $t$-test. 


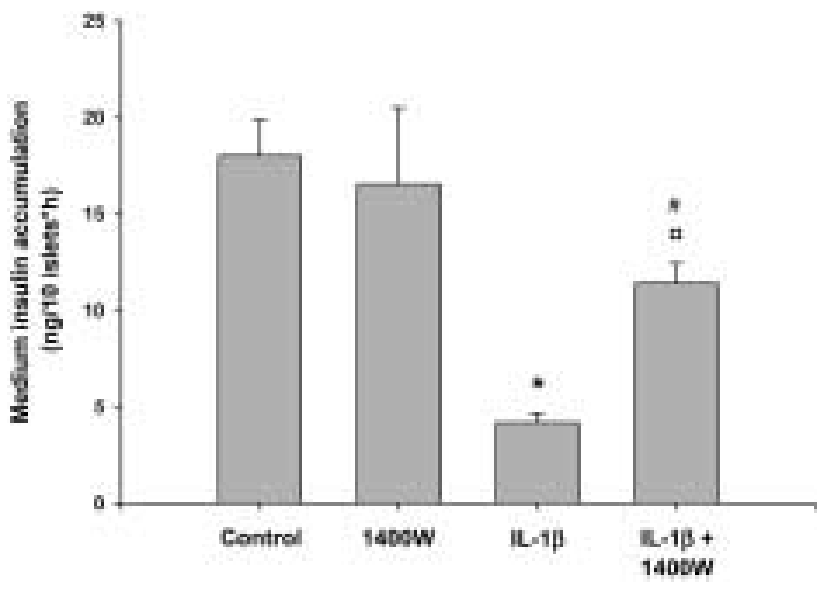

Figure 3 Insulin accumulation in medium during a 48-h incubation with islets with or without $1400 \mathrm{~W}(50 \mu \mathrm{mol} / \mathrm{l})$ and in the presence or absence of IL-1 $\beta(25 \mathrm{U} / \mathrm{ml})$. Values are means \pm S.E.M. for 10 experiments. * and a denote $P<0.001$ and $P<0.05$ respectively vs control value and \# denotes $P<0.01$ vs the IL-1 $\beta$ value, using one-way repeated ANOVA with subsequent all pairwise comparison procedures by Student-Newman-Keuls method.

Islets exposed to IL-1 $\beta$ had an insulin content which was $72 \%$ compared with control. With the addition of $1400 \mathrm{~W}(50 \mu \mathrm{mol} / \mathrm{l})$, the insulin content increased to $126 \%$ compared with control; this value was higher both compared with the IL-1 $\beta$ value and the control value (Fig. 5).

Analysis of the islets (pro)insulin biosynthesis during a 2-h incubation in $16.7 \mathrm{mmol} / \mathrm{l}$ glucose showed that islets previously cultured with IL-1 $\beta$ had a decreased synthesis to $58 \%$ compared with control. With the addition of $1400 \mathrm{~W}(50 \mu \mathrm{mol} / \mathrm{l})$ this decline was completely counteracted (Table 1). Although similar trends were observed for determinations of total protein biosynthesis and \% (pro)insulin of total protein, the only statistically significant difference seen here was an increase in total protein biosynthesis in islets exposed to IL- $1 \beta+1400 \mathrm{~W}$ compared with islets exposed to only IL-1 $\beta$ (Table $1)$.

Based on our in vitro results, we decided to test $1400 \mathrm{~W}$ in vivo to explore if the inhibitor could prevent the onset of diabetes in mice, induced by MLDS. Two different protocols were studied, and in both, the mice treated with STZ gradually developed hyperglycemia. None of the concentrations of $1400 \mathrm{~W}$ used in these experiments $(5.9 \mathrm{mg} / \mathrm{kg}$ body weight once a day, in the first, and $14 \mathrm{mg} / \mathrm{kg}$ body weight, twice a day, in the second) were able to prevent this (Figs 6 and 7). The administration of the inhibitor alone did not cause any change in blood glucose levels compared with the control group (treated only with saline). The inhibitor did not affect the body weight in any of the experiments.

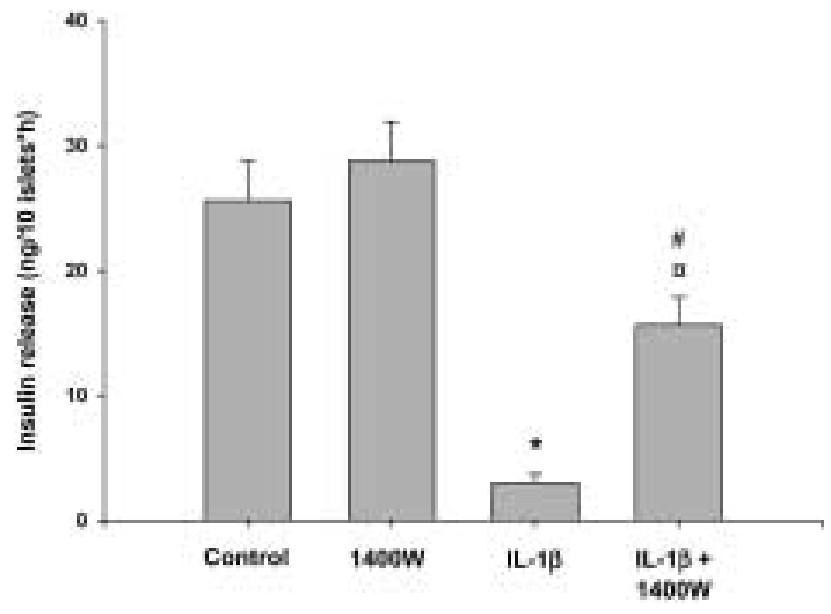

Figure 4 Insulin release by islets during a 90-min incubation in $16.7 \mathrm{mmol} / \mathrm{l}$ glucose. The islets had previously been incubated for $48 \mathrm{~h}$ with or without $1400 \mathrm{~W}(50 \mu \mathrm{mol} / \mathrm{l})$ and in the presence or absence of IL-1 $\beta(25 \mathrm{U} / \mathrm{ml})$. Values are means \pm S.E.M. for 10 experiments. * and $a$ denote $P<0.001$ and $P<0.01$ respectively vs control value and \# denotes $P<0.001$ vs the IL-1 $\beta$ value, using one-way repeated ANOVA with subsequent all pairwise comparison procedures by Bonferroni $t$-test.

Moreover, the administration of $1400 \mathrm{~W}$ did not appear to influence the progression of mononuclear cell infiltration or insulitis (Table 2).

To examine if $1400 \mathrm{~W}$ ( $14 \mathrm{mg} / \mathrm{kg}$ body weight) did function in vivo to reduce NO levels, we decided to determine $\mathrm{NO}_{x}$ plasma levels in mice exposed to different treatments (saline + saline, LPS + saline or LPS $+1400 \mathrm{~W}$ ). LPS was adopted as a strong inducer of iNOS. $\mathrm{NO}_{x}$ plasma levels were determined

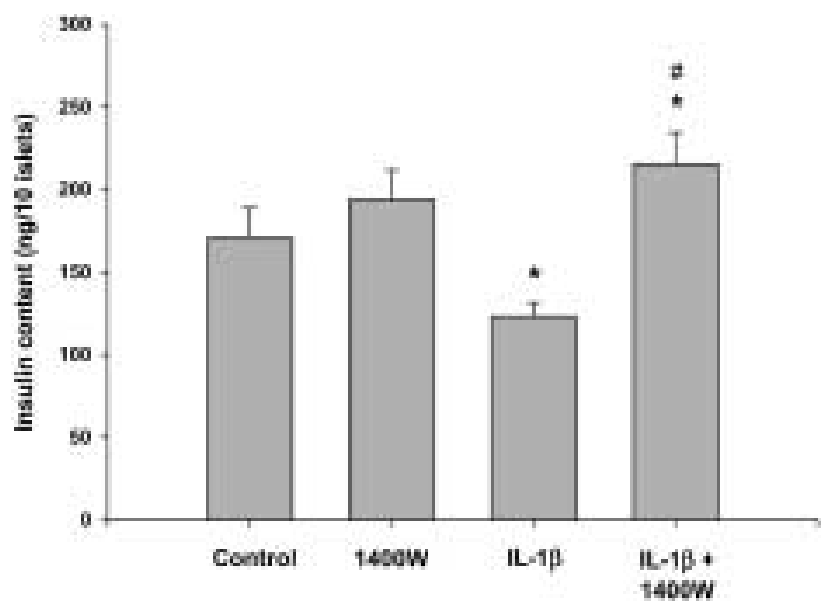

Figure 5 Effect of 48-h exposure of rat pancreatic islets to $1400 \mathrm{~W}(50 \mu \mathrm{mol} / \mathrm{l}), \mathrm{IL}-1 \beta(25 \mathrm{U} / \mathrm{ml})$, or both, on islet insulin content. The islets were exposed to a $16.7 \mathrm{mmol} / \mathrm{l}$ glucose solution for $90 \mathrm{~min}$ before insulin determination. Values are means \pm S.E.M. for nine experiments. * denotes $P<0.05$ vs control value and \# denotes $P<0.001$ vs the $\mathrm{IL}-1 \beta$ value, using one-way repeated ANOVA with subsequent all pairwise comparison procedures by Bonferroni $t$-test. 
Table 1 Effect of 48 -h exposure of rat pancreatic islets to $1400 \mathrm{~W}$, IL-1 $\beta$, or both, on (pro)insulin (PI) biosynthesis, total protein biosynthesis (TOT) and fraction PI of TOT compared with control. The concentrations used were $50 \mu \mathrm{M} 1400 \mathrm{~W}$ and $25 \mathrm{U} / \mathrm{ml} \mathrm{IL}-1 \beta$. The results are presented as means \pm S.E.M. for five experiments.

\begin{tabular}{lccc}
\hline Exposure & PI biosynthesis & TOT biosynthesis & $\begin{array}{c}\text { Fraction PI of TOT } \\
(\%)\end{array}$ \\
\hline Control & & $(\mathrm{dpm} / 10$ islets and $\mathrm{h})$ & $14.47 \pm 1.21$ \\
1400W & $934 \pm 271$ & $6065 \pm 1325$ & $15.01 \pm 1.25$ \\
IL-1 $\beta$ & $1084 \pm 383$ & $6745 \pm 1859$ & $10.93 \pm 2.33$ \\
IL-1 $\beta+1400 \mathrm{~W}$ & $542 \pm 205^{\star}$ & $4638 \pm 1279$ & $13.19 \pm 1.07$ \\
\hline
\end{tabular}

* denotes $P<0.05$ vs control, while \# and \#\# denote $P<0.05$ and $P<0.01$ respectively vs IL-1 $\beta$, using one-way repeated ANOVA with subsequent all pairwise comparison procedures by Student-Newman-Keuls method.
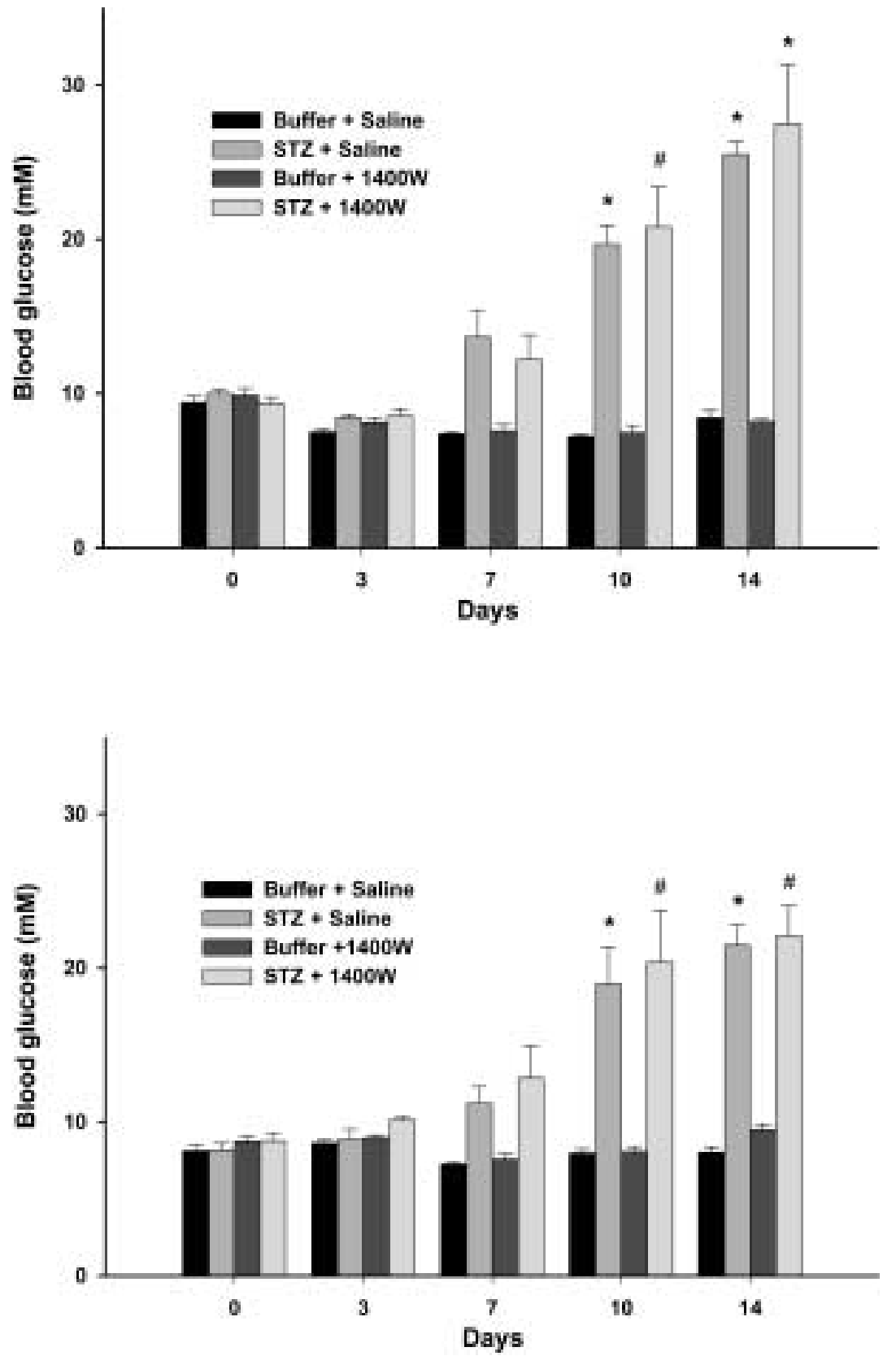

Figure 6 Blood glucose concentrations in mice treated with injections of either buffer + saline (black bars), STZ + saline (gray), buffer $+1400 \mathrm{~W}(5.9 \mathrm{mg} / \mathrm{kg}$ body weight) (dark gray) or STZ $+1400 \mathrm{~W}$ (light gray). Values are means \pm S.E.M. for five animals and ${ }^{*}$ and \# denote $P<0.001$ and $P<0.05$ respectively vs the corresponding value on day 0 , using one-way repeated ANOVA with subsequent all pairwise comparison procedures by Bonferroni $t$-test.
Figure 7 Blood glucose concentrations in mice treated with injections of either buffer + saline (black bars), STZ + saline (gray), buffer $+1400 \mathrm{~W}$ (14 mg/kg body weight) (dark gray) or STZ + 1400 W (light gray). Values are means \pm S.E.M. for five animals and ${ }^{*}$ and \# denote $P<0.001$ and $P<0.01$ respectively vs the corresponding value on day 0 , using one-way repeated ANOVA with subsequent all pairwise comparison procedures by Bonferroni $t$-test. 
Table 2 Effect of different treatment on mouse pancreatic islet morphology. During days 1-5 the buffer/STZ injections were given $30 \mathrm{~min}$ before the saline/1400 W injections. All injections were given intraperitoneally. In protocol 1 , the dose of $1400 \mathrm{~W}$ was $5.9 \mathrm{mg} / \mathrm{kg}$ body weight and day. However, in protocol 2, the dose of $1400 \mathrm{~W}$ was $28 \mathrm{mg} / \mathrm{kg}$ body weight and day and the saline/1400 W injection were given twice a day $(\sim 10 \mathrm{~h}$ between injections every day). After killing on day 14 , the pancreatic islet morphology was ranked according to an arbitrary scale. Rank $A$ denotes normal islet structure; rank $B$ denotes mononuclear cell infiltration in the islet peri-insular area; rank $C$ denotes heavy mononuclear cell infiltration into a majority of islets, i.e. insulitis; rank $D$ denotes only a few residual islets present, often showing an altered architecture and pyknotic cell nuclei.

\begin{tabular}{|c|c|c|c|c|c|c|}
\hline \multicolumn{3}{|c|}{ Treatment } & \multicolumn{4}{|c|}{ Morphology rank } \\
\hline Group & Days $1-5$ & Days $1-10$ & A & $\mathrm{B}$ & C & $\mathrm{D}$ \\
\hline \multicolumn{7}{|l|}{ Protocol 1} \\
\hline 1 & Buffer & Saline & 5 & 0 & 0 & 0 \\
\hline 2 & STZ & Saline & 0 & 0 & 4 & 1 \\
\hline 3 & Buffer & $1400 \mathrm{~W}$ & 5 & 0 & 0 & 0 \\
\hline 4 & STZ & $1400 \mathrm{~W}$ & 0 & 1 & 4 & 0 \\
\hline \multicolumn{7}{|c|}{ Protocol 2} \\
\hline 1 & Buffer & Saline & 5 & 0 & 0 & 0 \\
\hline 2 & STZ & Saline & 1 & 0 & 4 & 0 \\
\hline 3 & Buffer & $1400 \mathrm{~W}$ & 5 & 0 & 0 & 0 \\
\hline 4 & STZ & $1400 \mathrm{~W}$ & 0 & 0 & 3 & 2 \\
\hline
\end{tabular}

3, 6 and $10 \mathrm{~h}$ after the last injection. LPS caused a time-dependent and marked increase in plasma $\mathrm{NO}_{x}$ levels. Moreover, we found that the production of $\mathrm{NO}_{x}$ was effectively inhibited by $1400 \mathrm{~W}$ after 3,6 and $10 \mathrm{~h}$ (Fig. 8). There was no statistically significant difference between the groups that received LPS+ $1400 \mathrm{~W}$ and the control groups.

\section{Discussion}

The results from this study show that the new and selective iNOS inhibitor $1400 \mathrm{~W}$ can counteract the suppressive effect, induced by IL-1 $\beta$, on the function of rat islet $\beta$-cells in vitro. It was able to prevent completely the induced increase in medium nitrite accumulation and also to fully restore the reduction in glucose oxidation rate as well as the (pro)insulin biosynthesis. Since the elevation in nitrite formation was fully prevented at $50 \mu \mathrm{mol} / \mathrm{l} 1400 \mathrm{~W}$, we did not think it was worthwhile to use any higher concentrations of the drug. In the analysis of glucose-stimulated insulin release and medium insulin accumulation, however, only a partial protection was seen. This could suggest that the damage to the islet insulin release mechanism that could not be counteracted by $1400 \mathrm{~W}$ was caused by an NO-independent mechanism. This is in line with earlier findings that cytokines can cause NO-independent suppressive actions in $\beta$-cells $(8,19-21)$.

Although our in vitro results with $1400 \mathrm{~W}$ were promising, in the sense that IL-1 $\beta$ actions could be reduced at $\mu \mathrm{mol} / \mathrm{l}$ concentrations, rather than the $\mathrm{mmol} / \mathrm{l}$ concentrations often required with other NOS inhibitors, $1400 \mathrm{~W}$ failed to protect against MLDSinduced diabetes and the drug did not influence the progression of mononuclear cell infiltration in $\mathrm{C} 57 \mathrm{BL} / \mathrm{Ks}$ mice. However, we found that $1400 \mathrm{~W}$ effectively inhibited the LPS-induced increase in $\mathrm{NO}_{x}$ production in vivo, even $10 \mathrm{~h}$ after administration of $1400 \mathrm{~W}$. Systemic LPS administration leads to a potent iNOS activation by immune cells throughout the body. A similar systemic injection of $1400 \mathrm{~W}$ was in this context efficient in reducing plasma $\mathrm{NO}_{x}$ levels.

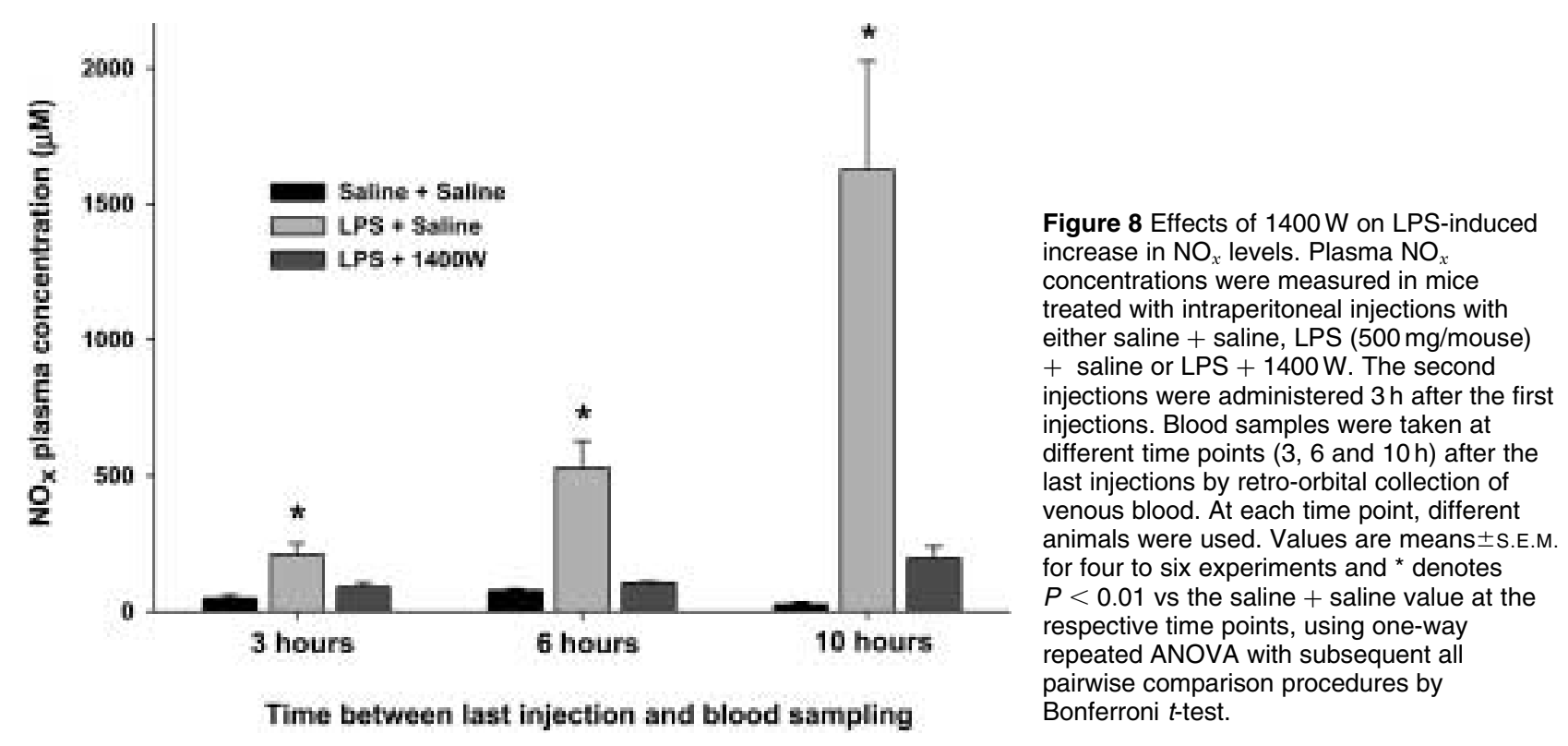


The question remains of how effectively $1400 \mathrm{~W}$ can inhibit iNOS activity at the level of the pancreatic islet, especially during insulitis. Furthermore, if iNOS is also expressed within $\beta$-cells leading to intracellular NO formation (22), it would be required that a sufficient amount of $1400 \mathrm{~W}$ is taken up by these cells. To our knowledge, no in vivo studies have been performed concerning the bioavailability of $1400 \mathrm{~W}$ in $\beta$-cells. We can therefore not exclude the possibility that our in vivo experiments failed due to an insufficient uptake of $1400 \mathrm{~W}$ within the islet $\beta$-cells. If this is the case, it could be that an even higher daily dose of $1400 \mathrm{~W}$ than used herein must be given in order to block NO at the islet $\beta$-cell level and perhaps prevent MLDSinduced diabetes. However, Garvey et al. showed that an intravenous dose of $50 \mathrm{mg} / \mathrm{kg}$ body weight $1400 \mathrm{~W}$ was lethal to mice and rats (13). On the other hand, when $1400 \mathrm{~W}$ was given as an intravenous infusion, a dose of $120 \mathrm{mg}$ /day for a 7-day period was tolerated (13).

The role of NO in type 1 diabetes animal models has been debated. For instance, it has been proposed that NO is not formed in the MLDS model (23). Moreover, in that model it has been reported that $\mathrm{N}^{\mathrm{G}}$-monomethyl-L-arginine was effective $(24)$, whilst $\mathrm{N}^{\mathrm{G}}$-nitroL-arginine was effective (25) or not effective (26) in counteracting the development of hyperglycemia, whereas aminoguanidine did not protect against hyperglycemia (27). Furthermore, iNOS knock-out mice were protected against MLDS-induced diabetes (11). In spontaneously diabetes-prone BB rats, $\mathrm{N}^{\mathrm{G}}$-monomethyl-L-arginine delayed the onset of diabetes (28) and $\mathrm{N}^{\mathrm{G}}$-nitro-L-arginine decreased the incidence of diabetes (29). Administration of aminoguanidine to NOD mice was found to slightly delay hyperglycemia (30) or to have no influence on diabetes or insulitis (31). In the latter animal model there are data suggesting that the iNOS gene is expressed in the pancreatic islets in the pre-diabetic phase, but it is not clear how this correlates to subsequent $\beta$-cell destruction and diabetes $(32,33)$.

Despite the failure to prevent MLDS-induced diabetes with $1400 \mathrm{~W}$, we think it is still warranted to further explore the possibility that iNOS inhibitors can be useful in preventing type 1 diabetes. The properties of such a drug would be a high selectivity for iNOS inhibition and a capacity for intracellular uptake. McMillan et al. (34) recently reported on findings with a class of substituted pyrimidine imidazoles that do not directly inhibit NOS activity, but very potently inhibit dimerization of iNOS during its synthesis and assembly. The inhibitors reported showed exceptional potency and high selectivity in cell-based assays, indicating superior cell permeability compared with other iNOS inhibitors (including $1400 \mathrm{~W}$ ).

Concerning human $\beta$-cells, it should be noted that studies performed on human pancreatic islets have shown them to be less sensitive towards cytokine-induced NO than mouse and rat pancreatic islets (35). Furthermore, to induce NO production in human islets, they must be exposed to combinations of cytokines, such as IL- $1 \beta+\operatorname{IFN}-\gamma$ (8). It is also likely that the time between the appearance of islet autoimmunity and the clinical onset of type 1 diabetes is much longer in humans than in mice and rats. Thus administration of an iNOS inhibitor over a prolonged period to individuals at risk of developing type 1 diabetes will require that the compound is very safe.

In conclusion, we have found that $1400 \mathrm{~W}$ was effective in preventing IL-1 $\beta$-induced inhibition of rat islet function and also in counteracting LPS-induced elevation of plasma nitrite. However, MLDS-induced diabetes was not prevented. The latter might be due to a failure by $1400 \mathrm{~W}$ in vivo to inhibit NO formation at the level of the pancreatic islet.

\section{Acknowledgements}

The skillful technical assistance of I-B Hallgren, A Nordin and E Törnelius are greatly acknowledged. We are thankful to Dr A King for linguistic advice and to Dr $\mathrm{N}$ Welsh for interesting discussions and valuable advice. This study was supported by grants from the Swedish Medical Research Council (72X-8273), the Swedish Diabetes Association, the Juvenile Diabetes Research Foundation, the Wallenberg Fund and the Ernfors Family Fund.

\section{References}

1 Bach J. Insulin-dependent diabetes mellitus as a $\beta$-cell targeted disease of immunoregulation. Journal of Autoimmunity $1995 \mathbf{8}$ 439-463.

2 Alderton WK, Cooper CE \& Knowles RG. Nitric oxide synthases: structure, function and inhibition. Biochemical Journal 2001 $357593-615$.

3 Förstermann U, Gath I, Schwarz P, Closs EI \& Kleinert H. Isoforms of nitric oxide synthase. Properties, cellular distribution and expressional control. Biochemical Pharmacology $1995 \mathbf{5 0}$ $1321-1332$.

4 Kolb H \& Kolb-Bachofen V. Type 1 (Insulin dependent) diabetes mellitus and nitric oxide. Diabetologia $199235796-797$.

5 Corbett JA \& McDaniel ML. Does nitric oxide mediate autoimmune destruction of $\beta$-cells? Diabetes $199241897-903$.

6 Wink D \& Mitchell JB. Chemical biology of nitric oxide: insights into regulatory, cytotoxic, and cytoprotective mechanisms of nitric oxide. Free Radical Biology and Medicine 199825 434-456.

7 Corbett JA \& McDaniel ML. Intraislet release of interleukin 1 inhibits $\beta$ cell function by inducing $\beta$ cell expression of inducible nitric oxide synthase. Journal of Experimental Medicine 1995181 559-568.

8 Eizirik DL, Sandler S, Welsh N, Cetkovic-Cvrlje M, Nieman A, Geller DA et al. Cytokines suppress human islet function irrespective of their effects on nitric oxide generation. Journal of Clinical Investigation 199493 1968-1974.

9 Rabinovitch A, Suarez-Pinzon W, Sorensen O \& Bleackley RC. Inducible nitric oxide synthase (iNOS) in pancreatic islets of non-obese diabetic mice: identification of iNOS expressing cells and relationships to cytokines expressed in the islets. Endocrinology $19961372093-2099$. 
10 Kleemann R, Rothe H, Kolb-Bachofen V, Xie Q, Nathan CN, Martin $\mathrm{S}$ et al. Transcription and translation of inducible nitric oxide synthase in the pancreas of prediabetic BB rats. FEBS Letters 1993328 9-12.

11 Flodström M, Tyrberg B, Eizirik DL \& Sandler S. Reduced sensitivity of inducible nitric oxide synthase-deficient mice to multiple low-dose streptozotocin-induced diabetes. Diabetes $199942706-713$.

12 Suarez-Pinzon WL, Mabley JG, Strynadka K, Power RF, Szabo C \& Rabinovitch A. An inhibitor of inducible nitric oxide synthase and scavenger of peroxynitrite prevents diabetes development in NOD mice. Journal of Autoimmunity 200116 449-455.

13 Garvey EP, Oplinger JA, Furfine ES, Kiff RJ, Laszlo F, Whittle BJR et al. $1400 \mathrm{~W}$ is a slow, tight binding, and highly selective inhibitor of inducible nitric-oxide synthase in vitro and in vivo. Journal of Biological Chemistry 1997272 4959-4963.

14 Green LC, Wagner DA, Golowski J, Skipper PL, Wishnok JS \& Tannenbaum SR. Analysis of nitrate, nitrite, and $\left[{ }^{15} \mathrm{~N}\right]$ nitrate in biological fluids. Analytical Biochemistry $1982 \mathbf{1 2 6} 131-138$.

15 Hinegardner RT. An improved fluorometric assay for DNA. Analytical Biochemistry 197139 197-201.

16 Halban PA, Wollheim CB, Blondel B \& Renold AE. Long-term exposure of isolated pancreatic islets to mannoheptulose: evidence for insulin degradation in the $\beta$-cell. Biochemical Pharmacology 198029 2625-2633.

17 Parmentier S, Böhme GA, Lerouet D, Damour D, Stutzmann J-M, Margaill I et al. Selective inhibition of inducible nitric oxide synthase prevents ischaemic brain injury. British Journal of Pharmacology 1999127 546-552.

18 Sandler S \& Andersson A. Modulation of streptozotocin-induced insulitis and hyperglycaemia in the mouse. Acta Pathologica, Microbiologica et Immunologica Scandinavica. Section A, Pathology 198593 93-98.

19 Rabinovitch A, Suarez-Pinzon W, Strynadka K, Schulz R, Lakey JR, Warnock GL et al. Human pancreatic islet $\beta$-cell destruction by cytokines is independent of nitric oxide production. Journal of Clinical Endocrinology and Metabolism 199479 1058-1062.

20 Dunger A, Cunningham JM, Delaney CA, Lowe JE, Green MH, Bone AJ et al. Tumor necrosis factor-alpha and interferongamma inhibit insulin secretion and cause DNA damage in unweaned rat islets. Extent of nitric oxide involvement. Diabetes $199645183-189$.

21 Andersson AK, Flodström M \& Sandler S. Cytokine-induced inhibition of insulin release from mouse pancreatic $\beta$-cells deficient in inducible nitric oxide synthase. Biochemical and Biophysical Research Communications 2001281 396-403.

22 Mandrup-Poulsen T, Corbett JA, McDaniel ML \& Nerup J. What are the types and cellular sources of free radicals in the pathogenesis of type 1 (insulin dependent) diabetes mellitus? Diabetologia 199336 470-471.

23 Papaccio G, Pisanti FA, Latronico MV, Ammendola E \& Galdieri M. Multiple low-dose and single high-dose treatments with streptozotocin do not generate nitric oxide. Journal of Cellular Biochemistry $20007782-91$
24 Lukic ML, Stosic-Grujicic S, Ostojic N, Chan WL \& Liew FY. Inhibition of nitric oxide generation affects the induction of diabetes by streptozotocin in mice. Biochemical and Biophysical Research Communications 1991178 913-920.

25 Kolb H, Kiesel U, Kröncke K-D \& Kolb-Bachofen V. Suppression of low dose streptozotocin induced diabetes in mice by administration of a nitric oxide synthase inhibitor. Life Sciences 1991 49 PL213-PL217.

26 Papaccio G, Esposito V, Latronico MV \& Pisanti FA. Administration of a nitric oxide synthase inhibitor does not suppress low-dose streptozotocin-induced diabetes in mice. International Journal of Pancreatology 199517 63-68.

27 Holstad M \& Sandler S. Aminoguanidine, an inhibitor of nitric oxide formation, fails to protect against insulitis and hyperglycemia induced by multiple low dose streptozotocin injections in mice. Autoimmunity $199315311-314$.

$28 \mathrm{Wu}$ G. Nitric oxide synthesis and the effects of aminoguanidine and $\mathrm{N}^{\mathrm{G}}$-monomethyl-L-arginine on the onset of diabetes in the spontaneously diabetic BB rat. Diabetes 1995 44 360-364.

29 Lindsay RM, Smith W, Rossiter SP, McIntyre MA, Williams BC \& Baird JD. $\mathrm{N}^{\omega}$-nitro-L-arginine methyl ester reduces the incident of IDDM in BB/E rats. Diabetes $1995 \mathbf{4 4} 365-368$.

30 Corbett JA, Mikhael A, Shimizu J, Frederick K, Misko TP, McDaniel ML et al. Nitric oxide production in islets of nonobese diabetic mice: aminoguanidine-sensitive and -resistant stages in the immunological diabetic process. PNAS $1993 \mathbf{9 0}$ $8992-8995$.

31 Bowman M, Simell O, Look Z, Luchetta R \& Atkinson M. Pharmacokinetic and therapeutic analysis of aminoguanidine (AG) in non-obese diabetic (NOD) mice. Diabetes $1994 \mathbf{4 3}$ (Suppl 1) 235A

32 Welsh M, Welsh N, Bendtzen K, Mares J, Strandell E, Öberg C et al. Comparison of mRNA contents of interleukin- $1 \beta$ and nitric oxide synthase in pancreatic islets isolated from female and male nonobese diabetic mice. Diabetologia 199538 153-160.

33 Rabinovitch A, Suarez-Pinzon WL, Sorensen O \& Bleackley RC. Inducible nitric oxide synthase (iNOS) in pancreatic islets of nonobese diabetic mice: identification of iNOS-expressing cells and relationships to cytokines expressed in the islets. Endocrinology $19961372093-2099$.

34 McMillan K, Adler M, Auld DS, Baldwin JJ, Blasko E, Browne LJ et al. Allosteric inhibitors of inducible nitric oxide synthase dimerization discovered via combinatorial chemistry. PNAS 200097 1506-1511.

35 Eizirik DL, Pipeleers DG, Ling Z, Welsh N, Hellerström C \& Andersson A. Major species differences between humans and rodents in the susceptibility to pancreatic $\beta$-cell injury. PNAS $1994919253-9256$.

Received 22 February 2002

Accepted 8 May 2002 